\title{
Polyethylene glycol-coated
}

ultrasmall superparamagnetic iron oxide nanoparticles-coupled sialyl Lewis X nanotheranostic platform for nasopharyngeal carcinoma imaging and photothermal therapy

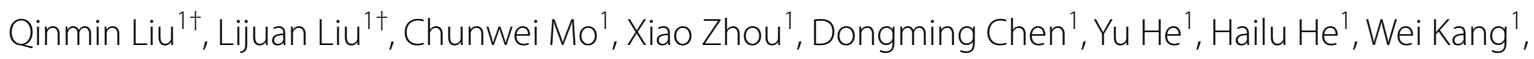
Yongfeng Zhao ${ }^{2}$ and Guanqiao Jin $^{1 *}$ (D)

\begin{abstract}
Background: Nasopharyngeal carcinoma (NPC) is a type of head and neck malignant tumor with a high incidence in specific regional distribution, and its traditional therapies face some challenges. It has become an urgent need to seek new therapeutic strategies without or with low toxicity and side effects. At present, more and more researchers has been attracting attention by nanotheranostic platform. Therefore, our team synthesized the polyethylene glycolcoated ultrasmall superparamagnetic iron oxide nanoparticles-coupled sialyl Lewis X (USPIO-PEG-SLe ${ }^{x}$ ) nanotheranostic platform with high temperature pyrolysis.

Results: The USPIO-PEG-SLe ${ }^{x}$ nanoparticles had excellent photothermal conversion property, and the temperature of USPIO-PEG-SLe ${ }^{x}$ nanoparticles solution increased with its concentration and power density of near-infrared (NIR) on $808 \mathrm{~nm}$ wavelengths. Five USPIO-PEG-sLe ${ }^{x}$ nanoparticles with different concentrations of $0 \mathrm{mg} / \mathrm{ml}, 0.025 \mathrm{mg} /$ $\mathrm{ml}, 0.05 \mathrm{mg} / \mathrm{ml}, 0.1 \mathrm{mg} / \mathrm{ml}$ and $0.2 \mathrm{mg} / \mathrm{ml}$ were prepared. The biological toxicity results showed that the viability of NPC 5-8F cells is related to the concentration of USPIO-PEG-sLe ${ }^{x}$ nanoparticles and the culture time $(P<0.001)$. The results of photothermal therapy (PTT) in vitro indicated that the viability of 5-8F cells decreased significantly with the concentration of USPIO-PEG-SLe ${ }^{x}$ nanoparticles increases $(P<0.001)$, and the viability of NPC 5-8F cells were $91.04 \% \pm 5.20 \%, 77.83 \% \pm 3.01 \%, 73.48 \% \pm 5.55 \%, 59.50 \% \pm 10.98 \%, 17.11 \% \pm 3.14 \%$, respectively. The USPIO-PEG-sLe ${ }^{x}$ nanoparticles could target the tumor area, and reduce the $T 2^{*}$ value of tumor tissue. The T2* values of tumor pre- and post-injection were $30.870 \pm 5.604$ and $18.335 \pm 4.351$, respectively $(P<0.001)$. In addition, USPIO-PEG-SLex nanoparticles as a photothermal agent for PTT could effectively inhibit tumor progression. The ratio of volume change between tail vein injection group, control group, nanoparticles without laser irradiation group and blank group after 5 treatments were $3.04 \pm 0.57,5.80 \pm 1.06,8.09 \pm 1.96,7.89 \pm 2.20$, respectively $(P<0.001)$.
\end{abstract}

\footnotetext{
*Correspondence: jinguanqiao77@gxmu.edu.cn

${ }^{\dagger}$ Qinmin Liu and Lijuan Liu contributed equally to this work

1 Department of Radiology, Guangxi Medical University Cancer Hospital, Nanning 530021, China

Full list of author information is available at the end of the article
}

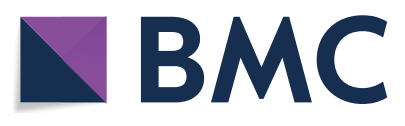

(c) The Author(s) 2021. This article is licensed under a Creative Commons Attribution 4.0 International License, which permits use, sharing, adaptation, distribution and reproduction in any medium or format, as long as you give appropriate credit to the original author(s) and the source, provide a link to the Creative Commons licence, and indicate if changes were made. The images or other third party material in this article are included in the article's Creative Commons licence, unless indicated otherwise in a credit line to the material. If material is not included in the article's Creative Commons licence and your intended use is not permitted by statutory regulation or exceeds the permitted use, you will need to obtain permission directly from the copyright holder. To view a copy of this licence, visit http://creativeco mmons.org/licenses/by/4.0/. The Creative Commons Public Domain Dedication waiver (http://creativecommons.org/publicdomain/ zero/1.0/) applies to the data made available in this article, unless otherwise stated in a credit line to the data. 
Conclusions: Our synthesized USPIO-PEG-SLe ${ }^{\mathrm{x}}$ nanotheranostic platform, and it may be become a new strategy for the treatment of NPC.

Keywords: Nasopharyngeal carcinoma, Nanotheranostic platform, USPIO-PEG-SLex , Magnetic resonance imaging, Photothermal therapy

\section{Background}

Nasopharyngeal carcinoma (NPC) is a type of head and neck malignant tumor with a high incidence in specific regional distribution. According to data in 2018 released by the International Agency for Research on Cancer (IARC), there are 129,079 new cases of NPC in worldwide [1], and $84.6 \%$ of the cases are in Asian countries, and the top three age-standardized rates are in Brunei, Penang, Malaysia and China [2]. In China, the vast majority of NPC occurs in five southern provinces, Guangdong, Guangxi, Hainan, Hunan, and Fujian [3]. The development of NPC is related to many factors, such as Epstein-Barr virus, environment, genetics [4], etc. Epstein-Barr virus, an independent risk factor, is closely related to the development and progression of NPC, especially undifferentiated NPC [5]. In the past few decades, the treatment strategies for NPC have been dominated by radiotherapy, chemotherapy or combination therapy [4]. However, these methods have some disadvantages. Radiation resistance has not only cause local progression, but also leads to a higher mortality [6]. Chemotherapy can easily bring systemic side effects to patients, and even death [7]. In emerging Immunotherapy, the different sensitivity of patients to Immunotherapy and combined with other treatment methods is still in clinical trials, and the existing immune resistance has become a bottle-neck in the application of Immunotherapy in NPC $[8,9]$. Therefore, seeking a non-invasive, low-toxic, and efficient treatment strategy for NPC has become an urgent clinical need. The nanotheranostic platform which is a Nanocarrier that integrates diagnosis and treatment, has been favored by the researchers [10]. Most of nanotheranostic platforms are nanocomposites with imaging function nanoparticles coupled to therapeutic agents. For example, Abed et al. synthesized Iron (III) oxide-gold (Fe2O3@Au) as a core-shell nanoparticles platform is used for magnetic resonance imaging (MRI) T2 sequence and photothermal therapy (PTT) [11]. Zhang et al. prepared Multi-walled carbon nanotubes-magnetofluorescent carbon dots/doxorubicin (GdN@C quantumQDs-MWCNTs) nanocomposites applied for MRI T1 sequence, and can be used for PTT and chemotherapy [12].

PTT emerged in the 1980's and has developed rapidly in the recent years. The basic principle of PTT is that a photothermal agent (PA) is absorbed light radiation, such as near-infrared (NIR) light, and generate heat energy so as to ablate tumor cells and regress the tumor (Fig. 1) [13]. Compared with traditional tumor treatment methods such as surgery, radiotherapy, chemotherapy, etc., PTT has many advantages like non-invasiveness, high specificity, high selectivity and controllability $[13,14]$. Now, most PAs of PTT are nanomaterials, which are divided into inorganic nanomaterials and organic nanomaterials [15]. Inorganic nanomaterial's mainly include metal nanomaterials,

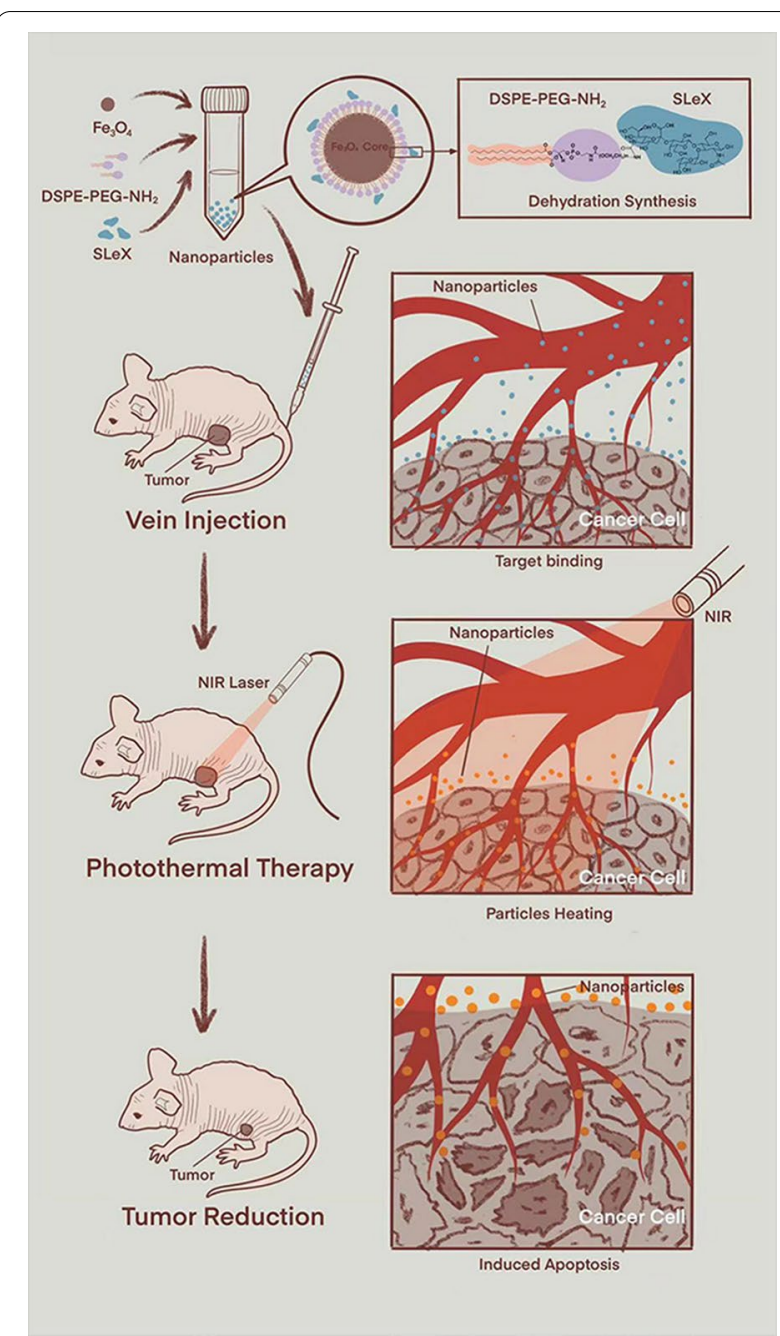

Fig. 1 Schematic diagram of PTT (using animal experimental research as a model) 
carbon-based nanomaterials, etc. [16, 17]. Some metal nanomaterials approved by the American Food and Drug Administration (FDA) as a contrast agent for the MRI in clinical, like ultrasmall superparamagnetic iron oxide (USPIO). USPIO nanoparticles can significantly increase the transverse relaxation rate of MRI, shorten the T2 value [18], and have no obvious biological toxicity [19]. In addition, due to the outstanding stability, excellent biocompatibility and photothermal conversion efficiency of USPIO nanoparticles, many researchers also explore USPIO nanoparticles or their chelates as PAs $[11,20]$. Now, nano-PAs has gotten extensive attention from more and more researchers as a nanotheranostic platform.

E-selectin is a kind of transmembrane protein, also known as CD62E, ELAM-1 and LECAM-2. Its primary structure consists of a C-type lectin-like domain, an epidermal growth factor-like domain and a complement-like domain, which has six repeats (about 60 amino acids per sequence) $[21,22]$. E-selectin often expressed in the vascular endothelial cells of inflammation or cancer [21,22]. Studies have shown that E-selectin related to the progression, metastasis and prognosis of a variety of malignant tumors, such as breast cancer [23], gastric cancer [24], and NPC [25]. The plasma membrane of cancer cells can also express the specific ligand of E-selectin, namely sialyl
Lewis X (sLe ${ }^{\mathrm{x}}$ ) (Fig. 2) [26], which might indicate that E-selectin is a natural target for anti-cancer therapy.

Therefore, in our study, our team synthesized polyethylene glycol (PEG)-coated USPIO nanoparticles-coupled sLe $^{\mathrm{x}}$ (USPIO-PEG-sLe ${ }^{\mathrm{x}}$ ) nanocomplex (Fig. 1), which had an outstanding dispersion, high stability, excellent T2 relaxation, and could targrt the E-selectin expression of tumor neovascular endothelial cells, and the USPIO-PEG-sLe ${ }^{\mathrm{x}}$ were performed for MRI and PTT of NPC nude mouse xenograft models as a nanotheranostic platform.

\section{Materials and methods \\ Materials}

Iron(III)2,4-pentanedionate, 1,2-hexadecanediol, oleic acid, oleylamine, EDC solid powder, phenyl ether and MES buffer solution were obtained from Shanghai Aladdin Company. Ethyl alcohol, hexyl hydride and trichloromethane were abtained from Shanghai Sinopharmm Group Chemical Reagent Co. LTD. DSPE-PEG2000 solid powder (A.V.T., Shanghai, China), sLe ${ }^{\mathrm{x}}$ (Carbosynth, UK), $808 \mathrm{~nm}$ near-infrared laser (BWT, Beijing, China), Digital thermometer (TES, Taipei, China), Cell Counting Kit-8 (Dojindo, Shanghai, China), Trypan blue staining kit (Solarbio, Beijing, China), 3.0T MRI scanner (Discovery MR750, GE Healthcare, USA), four-channel animal

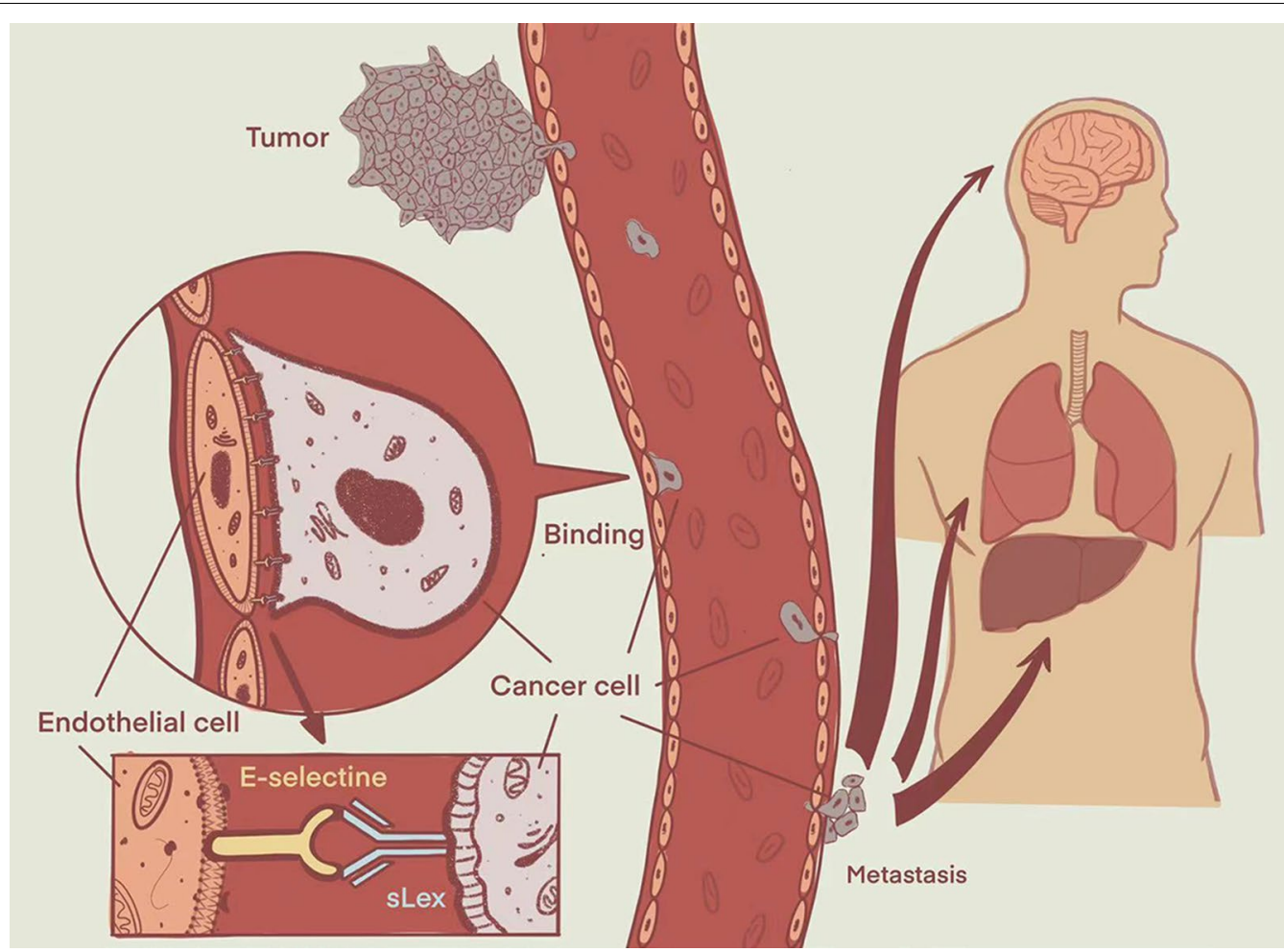

Fig. 2 Schematic diagram of the binding between $s L e^{x}$ and E-selectin 
coil (10F-04885, Teshen, Shenzhen, China), Near-infrared thermal imager (HIKVISION, Hangzhou, China), Prussian blue iron stain kit (Biotopped, Beijing, China), Hematoxylin-eosin stain kit (Solarbio, Beijing, China), Anti-CD62E antibody (Abcam, Shanghai, China).

\section{Synthesis of USPIO-PEG-sLe ${ }^{x}$}

$2 \mathrm{mmol}$ iron(III)2,4-pentanedionate, $10 \mathrm{mmol}$ 1,2-hexadecanediol, $20 \mathrm{ml}$ phenyl ether, $6 \mathrm{mmol}$ oleic acid and $6 \mathrm{mmol}$ oleylamine were heated to $200{ }^{\circ} \mathrm{C}$ for $1 \mathrm{~h}$, then heated to $256{ }^{\circ} \mathrm{C}$ for half an hour. The solution cooled to room temperature, and then added $40 \mathrm{ml}$ ethyl alcohol into the reaction solution. Centrifugation was conducted for $10 \mathrm{~min}$ at $6000 \mathrm{r} / \mathrm{min}$ to obtain black sediments. The process of ethanol precipitation/non-polar solvent dispersion was repeated 2-3 times to obtain the ferroferric oxide nanoparticles which with an average size of $6 \mathrm{~nm}$ and coated with oleic acid. The $84 \mathrm{mg}$ ferroferric oxide nanoparticles synthesized by the above method were dispersed in $4 \mathrm{~mL}$ hexyl hydride solution and then added with $2 \mathrm{mmol}$ iron(III)2,4-pentanedionate, $10 \mathrm{mmol}$ 1,2-hexadecanediol, $20 \mathrm{ml}$ phenyl ether, $6 \mathrm{mmol}$ oleic acid and $6 \mathrm{mmol}$ oleylamine to finally obtain the ferroferric oxide nanoparticles with an average size of $10 \mathrm{~nm}$. Took $50 \mathrm{mg}$ distearoyl phosphoethanolamine-PEG2000 (DSPE-PEG2000) solid powder dissolved in $5 \mathrm{ml}$ trichloromethane, then added $5 \mathrm{ml}$ ferroferric oxide nanoparticles solution. The mixed solution moved to $50 \mathrm{ml}$ round bottom flask and fully shocked $10 \mathrm{~min}$ via ultrasonic apparatus under $70{ }^{\circ} \mathrm{C}$, then $5 \mathrm{ml}$ deionized water was added. The flask was placed on a rotary evaporator, the water bath was $70{ }^{\circ} \mathrm{C}$, and the flask was pumped to vacuum before rotary evaporation. The samples were filtered by $220 \mathrm{~nm}$ filter membrane and then ultrafiltration centrifuged to remove the bottom sediment. USPIO-PEG nanoparticles were obtained by taking the solution with black and transparent aqueous phase nanostructure on the upper layer.

Dissolved $2 \mathrm{mg} \mathrm{sLe}{ }^{\mathrm{x}}$ in $2 \mathrm{ml}$ pure water to obtain $1 \mathrm{mg} /$ $\mathrm{ml} \mathrm{sLe} \mathrm{x}^{\mathrm{x}}$ solution. $1.1 \mathrm{ml}$ MES (0.15 mol/l, pH 5.5) buffer solution was added into $11 \mathrm{ml}$ USPIO-PEG nanoparticles and $120 \mathrm{ul} \mathrm{MES} \mathrm{(0.15} \mathrm{mol/l,} \mathrm{pH} \mathrm{5.5)} \mathrm{buffer} \mathrm{solution} \mathrm{was}$ added into $1.2 \mathrm{ml} \mathrm{sLe} \mathrm{x}^{\mathrm{x}}$ solution $(1 \mathrm{mg} / \mathrm{ml})$ to adjust the $\mathrm{pH}$ value. Then, the USPIO-PEG nanoparticles solution swirled into the $\mathrm{sLe}^{\mathrm{x}}$ solution and incubated for $30 \mathrm{~min}$ at $37{ }^{\circ} \mathrm{C}$ in a shaker, and $300 \mathrm{ul} \mathrm{1-(3-Dimethylaminopropyl)-}$ 3-ethylcarbodiimide hydrochloride (EDC) solution with a solubility of $10 \mathrm{mg} / \mathrm{ml}$ was added into the mixed solution and incubated at $37^{\circ} \mathrm{C}$ overnight. Then, the mixed solution was ultrafiltration for four times by 100KD ultrafiltration tube and pure water, and the excess EDC and unreacted $\mathrm{sLe}^{\mathrm{x}}$ were washed. After ultrafiltration, the suspension was diluted to $8 \mathrm{ml}$ with pure water, and the iron concentration was determined by phenanthroline spectrophotometric determination. Then, the concentration of USPIO-PEG$\mathrm{sLe}^{\mathrm{x}}$ nanoparticles solution with iron concentration of $1 \mathrm{mg} / \mathrm{ml}$ was obtained.

\section{Characterization of USPIO-PEG-sLe}

The size, shape, and dispersion of USPIO-PEG-sLe ${ }^{\mathrm{x}}$ were measured by transmission electron microscopy (TEM, JEM-2100, Japan). The hydrodynamic size and Zeta potential of the nanoparticles were measuured by dynamic light scattering (DLS) using the Zetasizer Nano ZS90 (Malven, UK). The Fourier Transform Infrared (FTIR) spectra was measured with the fourier infrared spectrometer (Thermo Nicolet, USA).

\section{Photothermal property test of USPIO-PEG-sLe ${ }^{\mathbf{x}}$ in vitro}

Dilute the USPIO-PEG-sLe ${ }^{x}$ nanoparticles solution with the pure water to five concentrations of $0 \mathrm{mg} / \mathrm{ml}, 0.025 \mathrm{mg} /$ $\mathrm{ml}, 0.05 \mathrm{mg} / \mathrm{ml}, 0.1 \mathrm{mg} / \mathrm{ml}$ and $0.2 \mathrm{mg} / \mathrm{ml} .1 \mathrm{ml}$ of each concentration placed into a glass colorimetry cup, and then a near-infrared laser with a wavelength of $808 \mathrm{~nm}$ to irradiate 5 different concentrations of USPIO-PEG-sLe ${ }^{\mathrm{x}}$. The power densities are $0.7 \mathrm{~W} / \mathrm{cm}^{2}, 1.4 \mathrm{~W} / \mathrm{cm}^{2}$, and $2.1 \mathrm{~W} / \mathrm{cm}^{2}$ for $10 \mathrm{~min}$, respectively. Recorded the temperature changes of different concentrations of USPIO-PEG-sLe ${ }^{\mathrm{x}}$ solution every $10 \mathrm{~s}$.

\section{Cytotoxicity test of USPIO-PEG-sLe ${ }^{\mathrm{x}}$}

Took 5-8F cells, during the logarithmic growth phase, they were planted in four 96-well plates, at a cell concentration of $5 \times 10^{4} / \mathrm{ml}$, inoculated $100 \mu \mathrm{L}$ of cell suspension per well, and then placed them into a constant temperature incubator at $37^{\circ} \mathrm{C}$ and $5 \% \mathrm{CO}_{2}$ concentration culture for $24 \mathrm{~h}$, and then took out and changed the medium. Each of the four experimental groups has 6 replicate wells. $10 \mu \mathrm{L}$ of the concentrations of USPIO-PEG-sLe ${ }^{\mathrm{x}}$ solution which included $0.025 \mathrm{mg} / \mathrm{ml}, 0.05 \mathrm{mg} / \mathrm{ml}, 0.1 \mathrm{mg} / \mathrm{ml}$, and $0.2 \mathrm{mg} / \mathrm{ml}$ was added to each well. In addition, set up a control group (without USPIO-PEG-sLe ${ }^{\mathrm{x}}$ solution) and a blank group (without cells and USPIO-PEG-sLex solution). The 96-well plates placed into a constant temperature incubator to culture for $2,4,8$, and $24 \mathrm{~h}$, respectively. Then took the 96-well plates out, discard the medium, and rinse three times with PBS buffer solution, then added $100 \mu \mathrm{L}$ of fresh medium and $10 \mu \mathrm{L}$ of CCK8 reagent to each well of each group.The 96-well plates then placed into constant temperature in the incubator for $2 \mathrm{~h}$. The absorbance at the wavelength of $450 \mathrm{~nm}$ recorded by a microplate reader. The cell viability is calculated by the following formula:

$$
\text { Cell viability }=[(\mathrm{As}-\mathrm{Ab}) /(\mathrm{Ac}-\mathrm{Ab})] \times 100 \%
$$


the As is the absorbance of the experimental well, Ac is the absorbance of the control well, $\mathrm{Ab}$ is the absorbance of the blank well.

\section{PTT of USPIO-PEG-sLe ${ }^{x}$ in vitro}

Took 5-8F cells in logarithmic growth phase, planted them in a 96-well plate at a cell concentration of $5 \times 10^{4}$ / $\mathrm{ml}$. Inoculated $100 \mu \mathrm{L}$ of cell suspension per well, and then placed the plate in a $37{ }^{\circ} \mathrm{C}$ constant temperature incubator, $5 \% \mathrm{CO}_{2}$ concentration for $24 \mathrm{~h}$. Each of the five experimental groups has 6 replicate holes. Five concentrations of USPIO-PEG-sLe ${ }^{\mathrm{x}}$ solution of $0 \mathrm{mg} / \mathrm{ml}$, $0.025 \mathrm{mg} / \mathrm{ml}, 0.05 \mathrm{mg} / \mathrm{ml}, 0.1 \mathrm{mg} / \mathrm{ml}$, and $0.2 \mathrm{mg} / \mathrm{ml}$ to replace the medium in the well. Each well then irradiated with $1.4 \mathrm{~W} / \mathrm{cm}^{2}$ NIR power density laser at $808 \mathrm{~nm}$ wavelength for $10 \mathrm{~min}$. Then, all wells were washed three times with PBS buffer. In addition, the control group (no USPIO-PEG-sLe ${ }^{\mathrm{x}}$ solution, no NIR irradiation) and a blank group (only complete medium, no NIR irradiation) set up. Three groups respectively added with $100 \mu \mathrm{L}$ of complete medium and $10 \mu \mathrm{L}$ of CCK8 reagent to each well. The plate placed in a constant temperature incubator at $37{ }^{\circ} \mathrm{C}, 5 \% \mathrm{CO}_{2}$ concentration for $2 \mathrm{~h}$. The cell viability described by the above formula. Dead cells stained in the experimental group with $0.4 \%$ trypan blue staining solution.

\section{MRI of USPIO-PEG-sLe ${ }^{\mathrm{x}}$ and USPIO-PEG, Prussian blue iron staining, and immunohistochemical (IHC) staining}

The MRI sequences included coronal T2WI, transverse T1WI, T2WI, and T2"map.

USPIO-PEG-sLe ${ }^{\mathrm{x}}$ nanoparticle solutions with concentrations of $0 \mathrm{mg} / \mathrm{ml}, 0.025 \mathrm{mg} / \mathrm{ml}, 0.05 \mathrm{mg} / \mathrm{ml}, 0.1 \mathrm{mg} /$ $\mathrm{ml}$, and $0.2 \mathrm{mg} / \mathrm{ml}$ installed in EP tubes in vitro MRI. After scanning, the T2*map of different concentrations of USPIO-PEG-sLe ${ }^{\mathrm{x}}$ nanoparticles was drawn through the MRI post-processing workstation.

BALB/C nude mice, purchased from the Experimental Animal Center of Guangxi Medical University (production license number is SCXK GUI 2014-0002, application license number is SYXK GUI 2014-003). 5-8F, configure the cell concentration to $1 \times 10^{7} / \mathrm{ml}$ with saline, and then configure it to $0.1 \mathrm{ml}$ of $5-8 \mathrm{~F}$ cell suspension, and then planted it subcutaneously on the right ventral side of each nude mouse. MRI examination was performed after 2 weeks. Twelve nude mice were randomly divided into USPIO-PEG-sLe ${ }^{x}$ group and USPIO-PEG group. The USPIO-PEG-sLe ${ }^{x}$ and USPIO-PEG nanoparticles were injected into the two group mice via the tail vein, respectively. Each group of nude mice were underwent MRI twice. The first MRI performed by the pre-injection of nanoparticles. One hour after injecting $0.1 \mathrm{ml}$ of nanoparticles through the tail vein, MRI was performed again.
The $\mathrm{T}_{2} *$ values of the tumors measured by the magnetic resonance post-processing workstation, and then differences in the $\mathrm{T}_{2}^{*}$ values pre- and post-injection of nanoparticles in each group analyzed. After the second MRI, nude mice are then sacrificed by the cervical spinal dislocation, and their tumors, brains, hearts, livers, kidneys, and spleens then collected. All tissues were fixed with $10 \%$ formalin.

Subsequently, all tissue specimens of the two groups were dehydrated and embedded in paraffin. Paraffin blocks were cut into $4 \mu \mathrm{m}$ thick sections. Prussian blue iron stain kit was used for iron staining. The positive area percentage of iron staining in different tissue was analyzed between the two groups. The expression of E-selectin in tumor specimens was analyzed by IHC staining, and differences of E-selectin in the USPIO-PEG-sLe ${ }^{\mathrm{x}}$ group and USPIO-PEG group were analyzed using mean optical density (MOD) by ImageJ measurement.

\section{PTT of USPIO-PEG-sLe ${ }^{\mathbf{x}}$ in vivo, HE staining of tumor}

24 tumor-burdened nude mice randomly divided into four groups: tail vein injection group, control group, nanoparticles without laser irradiation group and blank group. Nude mice in the tail vein injection group injected with $0.1 \mathrm{ml}$ of USPIO-PEG-sLe ${ }^{\mathrm{x}}$ nanoparticle via the tail vein for $1 \mathrm{~h}$ and then received PTT. The control group was performed PTT after injection of saline. The two groups irradiated for $10 \mathrm{~min}$ with a power density of $0.7 \mathrm{~W} / \mathrm{cm}^{2}$. The nanoparticles without laser irradiation group was injected with $0.1 \mathrm{ml}$ of USPIO-PEG-sLe $\mathrm{e}^{\mathrm{x}}$ nanoparticle via tail vein without PTT. The blank group received neither USPIO-PEG-sLe ${ }^{\mathrm{x}}$ nanoparticles nor PTT. During the treatment, a NIR thermal imaging device used to monitor the temperature change of the tumor in real time. There are $72 \mathrm{~h}$ between each treatment and a total of 5 treatments. The body weight and tumor size of nude mice were measured before and every three days after treatment. The tumor size calculated according to the following formula:

$$
\mathrm{V}=\mathrm{a} \times \mathrm{b}^{2} / 2
$$

There, $a$ is the long diameter of the tumor and $b$ is the short diameter of the tumor. After the five times' treatment, the four groups of nude mice sacrificed by cervical spinal dislocation to obtain tumors, and the tumors were fixed with $10 \%$ formalin.

Tumor specimens of nude mice in all groups were dehydrated and embedded in paraffin. The paraffin block was cut into $4 \mu \mathrm{m}$ thick sections, then the tumor specimens of each group of nude mice were stained with HE. The tumor cell apoptosis observed under the microscope via $\mathrm{HE}$ staining. 


\section{Statistical analysis}

SPSS 23.0 statistical software was used for data analysis. The data of each group were compiled by mean \pm standard deviation $(\overline{\mathrm{x}} \pm \mathrm{s})$. The differences were analyzed by paired t test, independent-samples $t$ test, analysis of variance (ANOVA) and Chi-square test. Differences between different groups was compared by LSD- $t$ test. Take $P \leq 0.05$, because the difference is statistically significant.

\section{Results}

Characterization of composition, hydrodynamic size, zeta potential, and fourier transform infrared spectroscopy

TEM showed that most of the USPIO-PEG-sLe ${ }^{\mathrm{x}}$ nanoparticles were square and polygonal, while a few were spherical (Fig. 3A). The dispersion degree was favorable, and the size of USPIO-PEG-sLe ${ }^{\mathrm{x}}$ was about $10 \mathrm{~nm}$ which was relatively uniform. The DLS showed that the number size of USPIO-PEG and USPIO-PEG-sLe ${ }^{\mathrm{x}}$ were

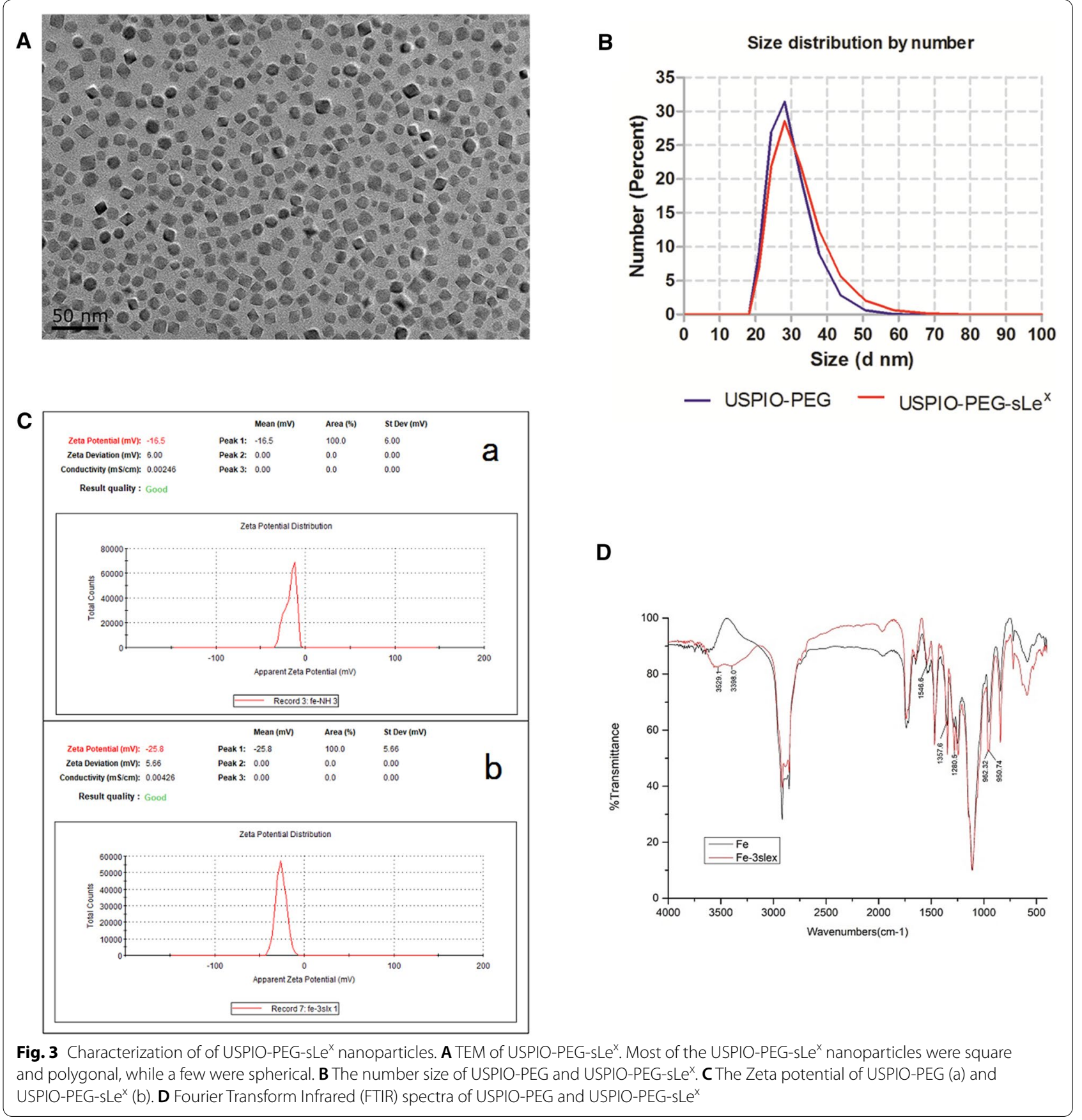


$28.9 \mathrm{~nm} \pm 5.596 \mathrm{~nm}$ and $30.65 \mathrm{~nm} \pm 7.061 \mathrm{~nm}$, respectively (Fig. 3B). This indicated that the distribution of nanoparticles size was narrow. The Zeta potential of USPIO-PEG and USPIO-PEG-sLe ${ }^{\mathrm{x}}$ were $-16.5 \pm 6 \mathrm{mV}$ and $-25.8 \pm 5.66 \mathrm{mV}$, respectively (Fig. $3 \mathrm{C}$ ). Owe to the presence of phospholipid groups in DSPE-PEG-NH $\mathrm{NH}_{2}$, USPIO-PEG had negative charge on its surface. After coupling with sLe ${ }^{\mathrm{x}}$, the Zeta potential of USPIO-PEG$\mathrm{sLe}^{\mathrm{x}}$ showed a larger negative charge. It may be because the amino groups on the surface of USPIP-PEG were occupied by sLex. The coupling between USPIO-PEG and $\mathrm{sLe}^{\mathrm{x}}$ was proved to be successful via hydrodynamic size and Zeta potential detection.

FTIR spectra (Fig. 3D) showed that double peaks appeared at $3529.1 \mathrm{~cm}^{-1}$ and $3398.0 \mathrm{~cm}^{-1}$, which was the stretching vibration peak of primary amide $\mathrm{N}-\mathrm{H}$ after coupling, and the stretching vibration peak of amide $\mathrm{C}-\mathrm{N}$ appeared at $1357.6 \mathrm{~cm}^{-1}$. The single peak at $960 \mathrm{~cm}^{-1}$ became a double peak of $962.32 \mathrm{~cm}^{-1}$ and $950.74 \mathrm{~cm}^{-1}$ owe to rolling vibration of methyl groups at the end of the pyran ring. The changes of pre- and postcoupling could been observed via the infrared spectrum, which indicated that USPIO-PEG and sLe ${ }^{\mathrm{x}}$ were successfully coupled.

\section{Photothermal property of USPIO-PEG-sLe ${ }^{\mathbf{x}}$ in vitro}

Through the photothermal property test of USPIOPEG-sLe ${ }^{x}$ in vitro, our results demonstrated that the temperature of USPIO-PEG-sLe ${ }^{x}$ nanoparticles solution increased with its concentration and power density of NIR on $808 \mathrm{~nm}$ wavelengths. As the concentration increases, the temperature of USPIO-PEG-sLe ${ }^{\mathrm{x}}$ nanoparticles solution increases significantly (Fig. 4A). The results show that USPIO-PEG-sLe ${ }^{\mathrm{x}}$ nanoparticles have excellent photothermal conversion property in different concentrations of nanoparticles.

\section{Cytotoxicity of USPIO-PEG-SLe}

We tested the cytotoxicity of USPIO-PEG-sLe ${ }^{\mathrm{x}}$ nanoparticles through Cell Counting Kit-8 (CCK8). Our results found that the viability of NPC $5-8$ F cells is related to the concentration of USPIO-PEG-sLe ${ }^{\mathrm{x}}$ nanoparticles and the cultrue time $(\mathrm{P}<0.001)$ (Table 1, Fig. 4B). When different concentrations of USPIO-PEG-sLe ${ }^{\mathrm{x}}$ nanoparticles were co-cultured with $5-8 \mathrm{~F}$ cells on $2 \mathrm{~h}$ and $4 \mathrm{~h}$, viability of NPC $5-8 \mathrm{~F}$ was no statistically significant difference between four concentration groups. However, when the co-culture time increased to $8 \mathrm{~h}$, viability of NPC $5-8 \mathrm{~F}$ between the $0.025 \mathrm{mg} / \mathrm{ml}$ concentration group and $0.1 \mathrm{mg} / \mathrm{ml}$ concentration group is statistically significant $(\mathrm{P}=0.027)$, and $0.2 \mathrm{mg} / \mathrm{ml}$ concentration group a statistically significant difference from the other groups $(\mathrm{P}<0.007)$, while the differences between the other groups are not statistically significant $(P>0.05)$. Cell viability was no difference between the concentrations of $0.1 \mathrm{mg} / \mathrm{ml}$ and $0.2 \mathrm{mg} / \mathrm{ml}$ at $24 \mathrm{~h}$ co-cultivation $(\mathrm{P}=0.242)$, the differences between the other groups were statistically significant $(\mathrm{P}<0.05)$. In addition, we analyzed the cell viability of $5-8 \mathrm{~F}$ cells co-cultured with the same concentration of USPIO-PEG-sLe ${ }^{\mathrm{x}}$ at different times. We found the cell viability differences between the $24 \mathrm{~h}$ time point and the other time points are statistically significant in the $0.025 \mathrm{mg} / \mathrm{ml}, 0.05 \mathrm{mg} / \mathrm{ml}$ and $0.1 \mathrm{mg} / \mathrm{ml}$ concentrations of USPIO-PEG-sLe ${ }^{\mathrm{x}}(\mathrm{P}<0.001)$, and the differences are not statistically significant between the other time points $(P>0.05)$. When the concentration of nanoparticles is $0.2 \mathrm{mg} / \mathrm{ml}$, the difference in cell viability at each time point is statistically significant $(\mathrm{P}<0.039)$ (Fig. 4C). Therefore, we conclude that USPIO-PEG-sLe ${ }^{\mathrm{x}}$ nanoparticles have slight cytotoxicity, but the increase in culture time and nanoparticle concentration will increase their toxicity.

\section{In vitro PTT of USPIO-PEG-SLe ${ }^{\mathbf{x}}$}

The results of PTT in vitro indicated that the viability of 5-8F cells decreased significantly with the concentration of USPIO-PEG-sLe ${ }^{\mathrm{x}}$ nanoparticles increases $(\mathrm{P}<0.001)$ (Table 2, Fig. 4D), when USPIO-PEG-sLe ${ }^{x}$ nanoparticles underwent the $1.4 \mathrm{~W} / \mathrm{cm}^{2}$ NIR power density and irradiated for $10 \mathrm{~min}$. There was no statistically significant difference between the concentrations of $0.025 \mathrm{mg} / \mathrm{ml}$ and $0.05 \mathrm{mg} / \mathrm{ml}$ group $(\mathrm{P}=0.242)$. The differences between the other groups were statistically significant $(\mathrm{P}<0.001)$. These results meant that the high the concentration of nanoparticles had good PTT effect in vitro in the safe concentration range. Trypan blue cell staining also showed that the cell viability of $5-8 \mathrm{~F}$ cells decreased with the increase of nanoparticles concentration (Fig. 4E).

\section{MRI of USPIO-PEG-sLe ${ }^{\mathrm{x}}$ and USPIO-PEG, Prussian blue iron staining, and IHC staining}

Our results showed that in vitro MRI, different concentrations of USPIO-PEG-sLe ${ }^{\mathrm{x}}$ nanoparticles have a higher concentration of visible signal changes to the naked eye, increase the transverse relaxation rate, shorten the $\mathrm{T} 2$ relaxation time and reduce the T2 value (Fig. 5A).

In the USPIO-PEG-sLe ${ }^{\mathrm{x}}$ group, compared with the tumor T2* value pre-injection of USPIO-PEG-sLe ${ }^{\mathrm{x}}$ nanoparticles in vivo MRI, the tumor $\mathrm{T}^{*}$ value of tumor-burdened nude mice post-injection was lower, the $\mathrm{T}^{*}$ values was $30.870 \pm 5.604$ and $18.335 \pm 4.351$, respectively (Fig. $5 \mathrm{~B}, \mathrm{C}$ ), the difference was statistically significant $(\mathrm{P}<0.001)$. In the USPIO-PEG group, T2* values of pre- and post-injection was $21.465 \pm 6.509$ and $16.419 \pm 6.910$, respectively (Fig. $5 \mathrm{~B}, \mathrm{C}$ ), the difference was statistically significant $(\mathrm{P}<0.001)$. 


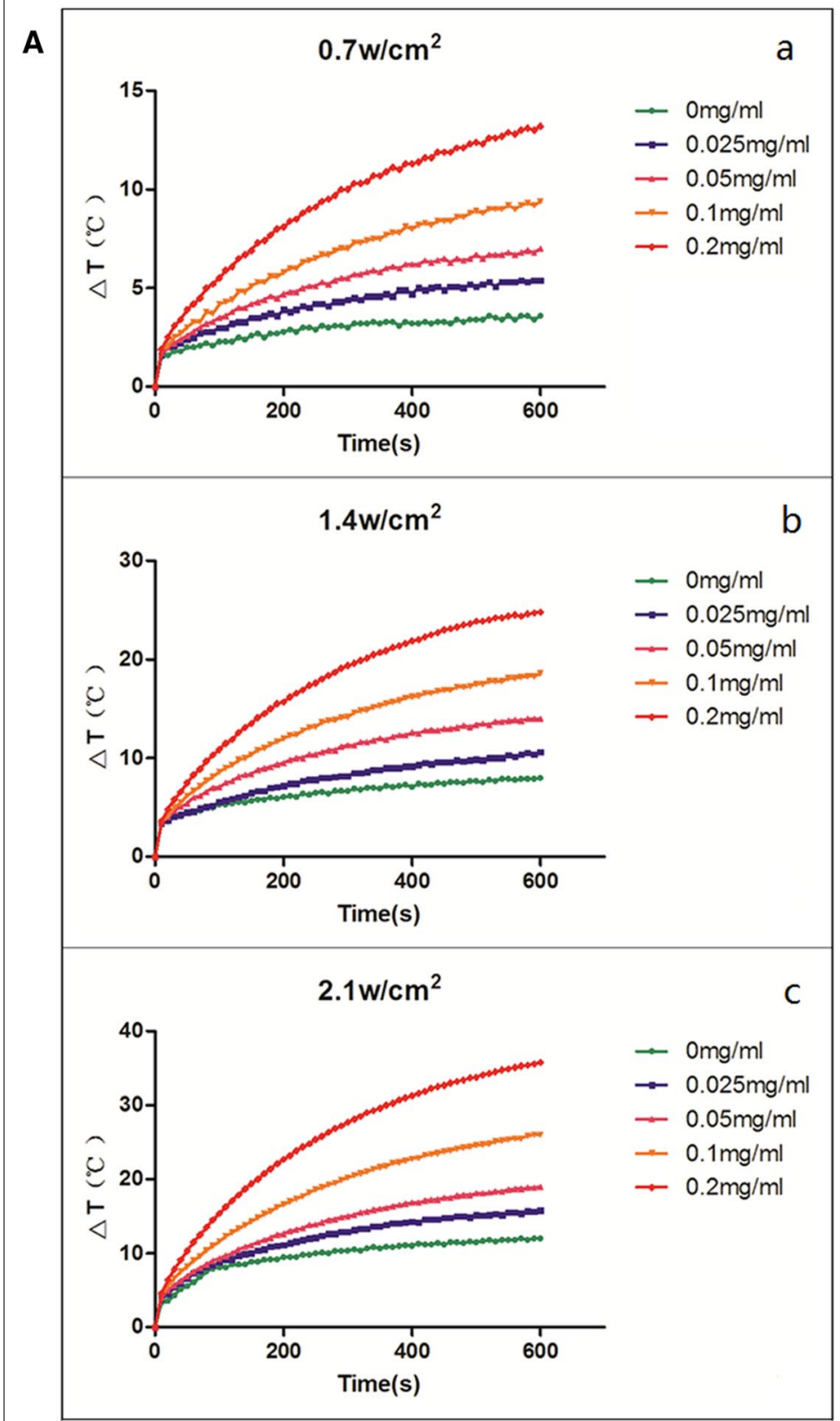

B

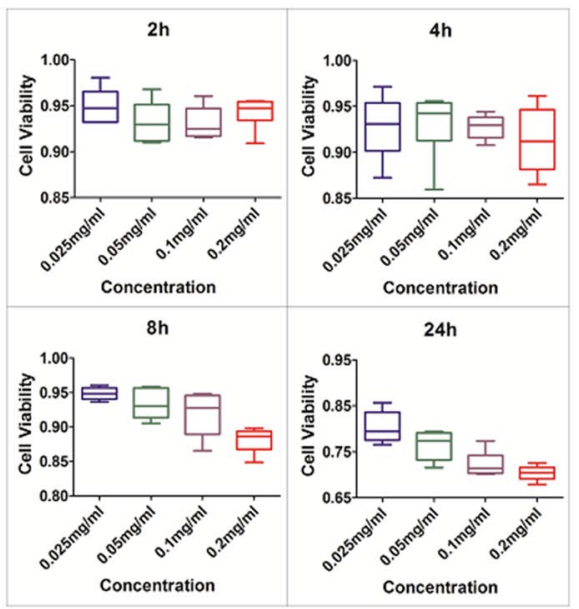

C
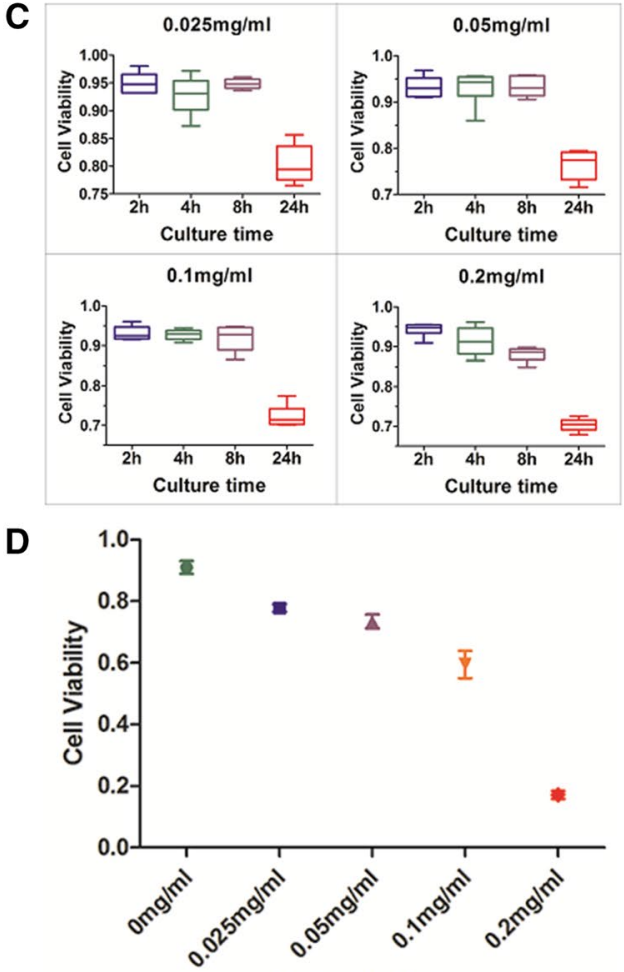

Concentration

$\mathbf{E}$

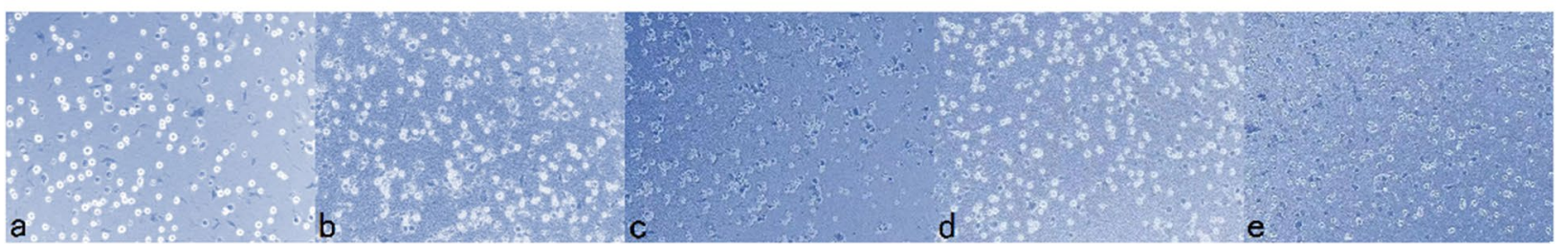

Fig. 4 A The temperature changes of five different concentrations of USPIO-PEG-sLe ${ }^{x}$ nanoparticles under different power densities of NIR (a, b, and c) with a wavelength of $808 \mathrm{~nm}$. B Cell viability of USPIO-PEG-sLe nanoparticles co-cultured with5-8F cells for $2 \mathrm{~h}, 4 \mathrm{~h}, 8 \mathrm{~h}, 24 \mathrm{~h}$. C Cell viability of 5-8F cells in same concentration of USPIO-PEG-SLe ${ }^{x}$ nanoparticles at different culture times. D Cell viability of 5-8F cells with different concentrations USPIO-PEG-sLe ${ }^{x}$ nanoparticles in vitro PTT. E Trypan blue staining. Dead cells were stained blue, while living cells were translucent. The cell viability of each concentration was $80.00 \%, 75.21 \%, 78.33 \%, 75.80 \%, 69.45 \%$, respectively $(a, 0$ mg/ml, b, $0.025 \mathrm{mg} / \mathrm{ml}, \mathrm{c}, 0.05 \mathrm{mg} / \mathrm{ml}, \mathrm{d}, 0.1 \mathrm{mg} / \mathrm{ml}, \mathrm{e}, 0.2 \mathrm{mg} /$ $\mathrm{ml})$ 
Table 1 Cell viability of 5-8F cells co-cultured with different concentrations of USPIO-PEG-SLe ${ }^{x}$ nanoparticles at different time points

\begin{tabular}{llllll}
\hline Concentration & $\mathbf{n}$ & Cell Viability & & & \\
\cline { 3 - 6 } & & $\mathbf{2 h}$ & $\mathbf{4 h}$ & $\mathbf{8 h}$ & $\mathbf{2 4 h}$ \\
\hline $0.025 \mathrm{mg} / \mathrm{ml}$ & 6 & $95.00 \% \pm 1.92 \%$ & $92.75 \% \pm 3.37 \%$ & $94.83 \% \pm 0.91 \%$ & $80.32 \% \pm 3.39 \%$ \\
$0.05 \mathrm{mg} / \mathrm{ml}$ & 6 & $93.25 \% \pm 2.35 \%$ & $93.07 \% \pm 3.62 \%$ & $93.27 \% \pm 2.12 \%$ & $76.42 \% \pm 3.12 \%$ \\
$0.1 \mathrm{mg} / \mathrm{ml}$ & 6 & $93.09 \% \pm 1.76 \%$ & $92.77 \% \pm 1.29 \%$ & $91.86 \% \pm 3.18 \%$ & $72.29 \% \pm 2.74 \%$ \\
$0.2 \mathrm{mg} / \mathrm{ml}$ & 6 & $94.26 \% \pm 1.72 \%$ & $91.31 \% \pm 3.55 \%$ & $88.10 \% \pm 1.78 \%$ & $70.34 \% \pm 1.64 \%$ \\
\hline
\end{tabular}

Table 2 Cell viability of 5-8F cells with different concentrations USPIO-PEG-SLex nanoparticles in vitro PTT

\begin{tabular}{lllll}
\hline Concentration & $\mathbf{n}$ & Cell Viability & F Value & P value \\
\hline $0 \mathrm{mg} / \mathrm{ml}$ & 6 & $91.04 \% \pm 5.20 \%$ & 122.917 & $\mathrm{P}<0.001$ \\
$0.025 \mathrm{mg} / \mathrm{ml}$ & 6 & $77.83 \% \pm 3.01 \%$ & & \\
$0.05 \mathrm{mg} / \mathrm{ml}$ & 6 & $73.48 \% \pm 5.55 \%$ & & \\
$0.1 \mathrm{mg} / \mathrm{ml}$ & 6 & $59.50 \% \pm 10.98 \%$ & & \\
$0.2 \mathrm{mg} / \mathrm{ml}$ & 6 & $17.11 \% \pm 3.14 \%$ & & \\
\hline
\end{tabular}

In addition, we analyzed the $\mathrm{T} 2 *$ difference value $(\Delta \mathrm{T} 2 *$ value) between the two groups pre- and post-injection. In the USPIO-PEG-sLe ${ }^{\mathrm{x}}$ group and the USPIO-PEG group, the $\Delta \mathrm{T} 2 *$ value were $12.535 \pm 1.730$ and $5.046 \pm 1.366$, respectively. The difference was statistically significant $(\mathrm{P}<0.001)$ (Fig. 5D). The results showed that both USPIO-PEG-sLe ${ }^{\mathrm{x}}$ nanoparticles and USPIO-PEG nanoparticles reduced the $\mathrm{T} 2 *$ value in tumor area, especially USPIO-PEG-sLe ${ }^{\mathrm{x}}$ nanoparticles. This means that USPIOPEG-sLe ${ }^{\mathrm{x}}$ nanoparticles has a targeted property. Moreover, USPIO-PEG nanoparticles can also reduce the T2* value in tumor area, and we inferred that the USPIOPEG nanoparticles reached to tumor tissue through the tumor blood vessels.

We performed the Prussian blue iron staining on the tumor specimens. We found that a few iron nanoparticles were stained blue in the tumor tissue in the USPIO-PEG group (Fig. 6Aa). By contrast, the amount of iron in the USPIO-PEG-sLe ${ }^{\mathrm{x}}$ group was statistically more than that of the USPIO-PEG group (Fig. 6Ab). The results further explain why the decrease in $2^{*}$ value of tumor tissue in the USPIO-PEG group after post-injection was not as significant as that in the USPIO-PEG-sLe ${ }^{\mathrm{x}}$ group. We believe that USPIO-PEG-sLe ${ }^{\mathrm{x}}$ nanoparticles can target the tumor area and can be used as a T2 contrast agent to perform MRI on nude mouse xenograft tumor models.

Prussian blue iron staining of hearts, livers, kidneys, spleens, and muscle were shown in Fig. 6B. The results showed that in both the USPIO-PEG-sLe ${ }^{\mathrm{x}}$ group and the USPIO-PEG group, the nanoparticles concentrated in the liver, and there was also a small amount of iron in the

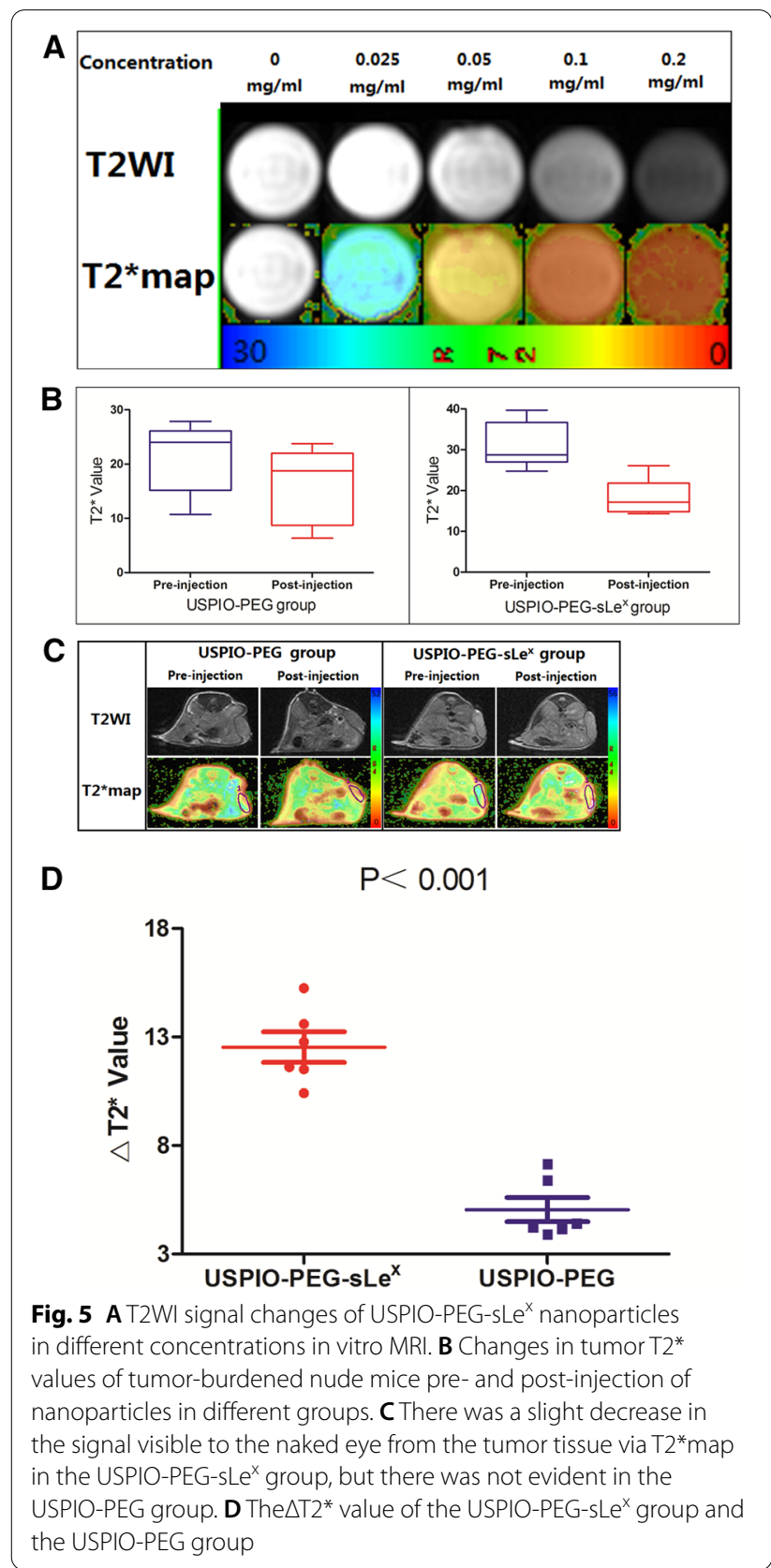


Fig. 6 A Prussian blue iron staining of tumor specimens. (a, USPIO-PEG group, and there was a small amount of iron particles

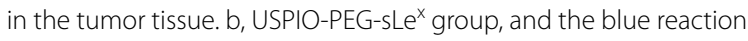
products were diffuse in the tumor.) $\mathbf{B}$ Prussian blue iron staining of different tissues. In A and B, The blue particles were iron particles and the red backgroud were tumor tissue $(A)$ and normal organ tissue (B) (a, C, e, g, and i are liver, spleen, heart, kidney and muscle of nude mice in the USPIO-PEG group, respectively. And b, d, f, h, and $\mathrm{j}$ are liver, spleen, heart, kidney and muscle of nude mice in the USPIO-PEG-SLe group). C IHC staining. The brown area was the antigen-antibody reaction product, and the blue area was the nucleus. The expression of E-selectin was low positive in the both group (a, USPIO-PEG group and b, USPIO-PEG-SLe $e^{x}$ group). And it could be seen both cytoplasm and membrane

spleens, but hardly any in other organs. This implied that the targeted component sLe ${ }^{\mathrm{x}}$ has no effect on the biodistribution of USPIO-PEG, and iron is mainly metabolized through the liver in mice.

IHC analysis showed brown reaction products of tumors specimens in two groups, but the expression level was low (Fig. 6C). The IHC results of tumor specimens in both groups were low positive via ImagJ software annalysis. It indicated that E-selectin of xenograft model was a low expression state.

\section{PTT of USPIO-PEG-sLe ${ }^{\mathbf{x}}$ in vivo}

The real-time temperature of PTT treatment in the tail vein injection group and the control group was monitored with NIR imager. Our results showed that after 10 min of NIR light irradiation, the temperature of the tumor tissue in the tail vein injection group was higher than that in the control group (Table 3, Fig. 7A), and the difference was statistically significant $(\mathrm{P}<0.001)$. The result showed that the tail vein injection group had USPIO-PEG-sLe ${ }^{\mathrm{x}}$ at the tumor site. This is consistent with the results of in vivo MRI experimental studies.

We recorded the temperature changes in the tumor tissue and surrounding tissue pre- and post-treatment in the tail vein injection group and the control group (Fig. 7B, C). Changes of tumor pre- and post-treatment were also recorded (Fig. 8). Volume measurement in the xenograft tumor between the tail vein injection group, the control group, the nanoparticles without laser irradiation group and the blank group. Our results indicate the ratio of the volume change between tail vein injection group, control group, nanoparticles without laser irradiation group and blank group after 5 treatments was $3.04 \pm 0.57,5.80 \pm 1.06,8.09 \pm 1.96,7.89 \pm 2.20$, respectively (Fig. 7D, 7E). The difference between these four groups are statistically significant $(\mathrm{P}<0.001)$. Pairwise comparisons between nanoparticles without laser irradiation group and blank group was no statistically significant difference $(\mathrm{P}=0.828)$. The differences among
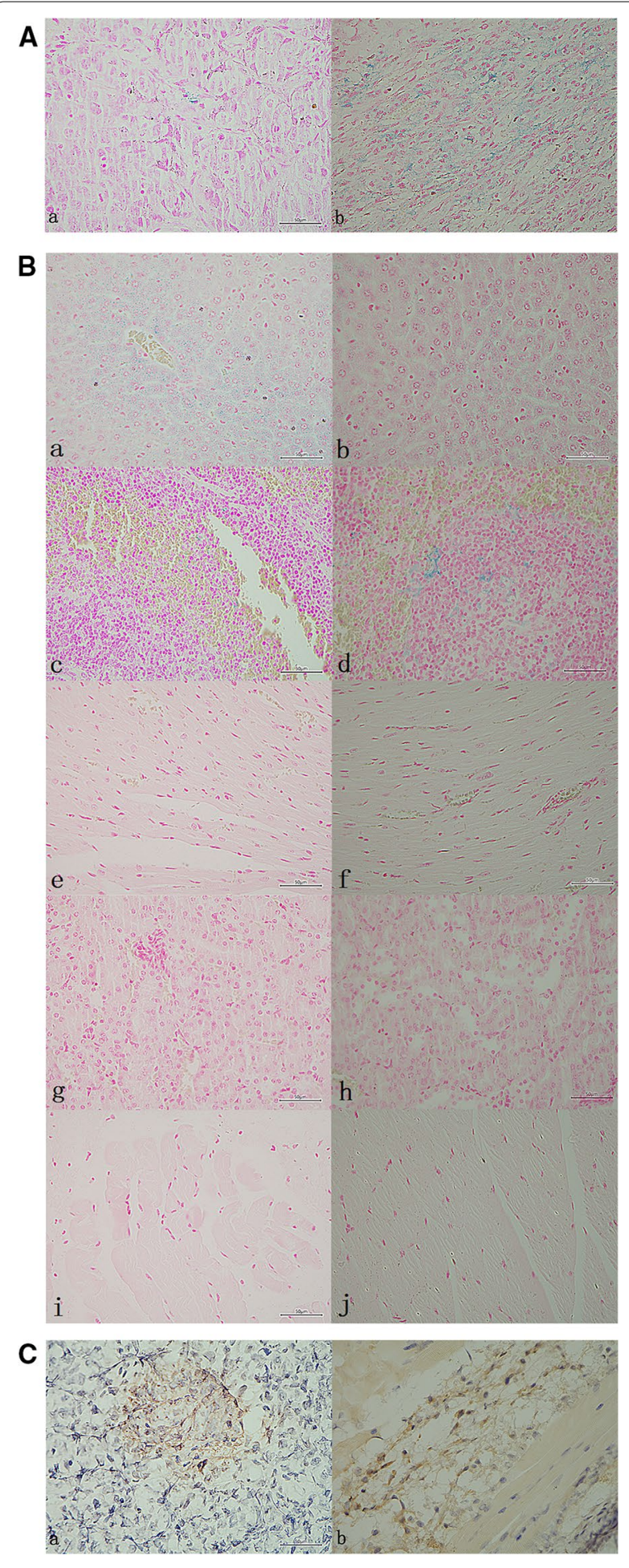

other groups were statistically significant (tail vein injection group vs control group $\mathrm{P}=0.007$, tail vein injection group vs nanoparticles without laser irradiation group $\mathrm{P}<0.001$, tail vein injection group vs blank group $\mathrm{P}<0.001$, control group vs nanoparticles without laser 
Table 3 Comparison of the highest temperature in the two groups of nude mice xenografts after 10 min of NIR light irradiation

\begin{tabular}{lllll}
\hline Group & $\mathbf{n}$ & $\begin{array}{l}\text { Maximum } \\
\text { temperature }\left({ }^{\circ} \mathbf{C}\right)\end{array}$ & t Value & P value \\
\hline Tail vein injection & 6 & $43.267 \pm 0.493$ & 7.387 & $P<0.001$ \\
Control & 6 & $41.417 \pm 0.366$ & & \\
\hline
\end{tabular}

irradiation group $\mathrm{P}=0.021$, control group vs blank group $\mathrm{P}=0.034$, respectively). During the experiment period, no tumor-burdened nude mice died, and the average weight of tumor-burdened nude mice in all four groups increased (Fig. 7F), which indirectly indicated that the USPIO-PEG-sLe ${ }^{\mathrm{x}}$ nanoparticles has no obvious biological toxicity and will not cause cachexia in the short term. Therefore, we believe that USPIO-PEG-sLe ${ }^{\mathrm{x}}$ nanoparticles can significantly inhibit tumor progression and can serve as a nanothermal platform for PTT.

\section{HE staining}

Our HE staining results found that more apoptotic cells detected in the tumor specimens of the tail vein injection group in the PTT in vivo, but not in the control group, nanoparticles without laser irradiation group and the blank groups (Fig. 7G). Compared with the other groups, the tumor progression in the tail vein injection group was significantly inhibited. The PTT caused more tumor cells apoptosis, but PTT did not kill the tumor cells. We speculated that the E-selectin was a low expression state on the surface of vascular endothelial cells for the absence of metastasis or weak invasion in our xenograft model. It resulted in a low concentration of USPIO-PEG-sLe ${ }^{\mathrm{x}}$ nanoparticles targeting the tumor site, and failed to cause obvious apoptosis in tumor cells. The results of IHC staining can also verify our inference.

\section{Discussion}

We have prepared a nanotheranostic platform for MRI and PTT in human NPC xenografts on mice model. We have confirmed that the nanotheranostic platform have two functions for MRI and PTT, and can predominately inhibit xenografts tumor progression in vivo and in vitro experiment. Although there were several similar systems that could be used for MRI and PTT, our synthesized nanoparticles had some advantages. E-selectin overexpression is associated with tumor metastasis, and studies have found that E-selectin expressed in a variety of tumor tissues, such as NPC [21]. Therefore, our nanotheranostic platform could be effectively applied in photothermal therapy and molecular imaging of a variety of tumors. In addition, the chemotherapy dilemma of local advanced NPC treatments were low selectivity and large side effects. Our nanotheranostic platform can accurately target the tumor region, improve the selectivity and have fewer side effects in NPC treatment.

PTT based on tumor blood vessels may remodel of the Cell-cell and cell-extracellular matrix which seems promising for decreasing mechanical stress in the tumor microenvironment, the degradation of such components may also have unwanted outcomes, such as promoting invasiveness and migration of cancer cells [27, 28]. In future, We need for improved understanding and careful design of targeted regimens, and PTT is not necessarily in one singular strategy, but rather the development of leverage double or multiple regimes, such as simple thermotherapy (hyperthermia) combined low-dose sunitinib (anti-angiogenic therapy) [29,30].

At present, the bottleneck of NPC treatments are low selectivity and large side effects. However, the nanotheranostic platform we prepared can accurately target the tumor region, improve the selectivity of treatment, and have fewer side effects. It might break the bottleneck. PTT has become a new strategy for anti-tumor treatment due to its many advantages, but each treatment has its advantages and limitations. Although PTT can inhibit tumor growth and promote cell apoptosis, it is not feasible to use PTT alone for anti-tumor therapy and only be used as adjuvant therapy. And a lot of research has been done on PTT in combination with other strategies. How to improve the targeting property and photothermal conversion efficiency and control the therapeutic concentration of PAs in the target area is

\footnotetext{
(See figure on next page.)

Fig. 7 A The highest temperature of nude mice xenografts in different groups after 10 min of NIR light irradiation. B Tail vein injection group. "+" is the highest temperature area which measured by NIR imager. (a) Tumor before treatment, (b) Tumor after 5 treatments, (c) The maximum temperature is $33.8^{\circ} \mathrm{C}$ (non-tumor tissue temperature) before treatment, (d) The maximum temperature after 10 min of treatment (tumor tissue temperature) reached $43.7^{\circ} \mathrm{C}$. C Control group. " + " is the highest temperature area which measured by NIR imager. (a) Tumor before treatment, (b) Tumor after treatment 5 times, (c) The highest temperature before treatment is $34.0^{\circ} \mathrm{C}$ (non-tumor tissue temperature), (d) The highest temperature after treatment reaches $41.8^{\circ} \mathrm{C} 10 \mathrm{~min}$ (tumor tissue temperature). $\mathbf{D}$ and $\mathbf{E}$ Changes in tumor volume pre- and post-treatment in the tail vein injection group, control group, nanoparticles without laser irradiation group and blank group. $\mathbf{F}$ Changes of weight in nude mice pre- and post-treatment among the tail vein injection group, control group, nanoparticles without laser irradiation group and blank group. G HE staining. More apoptotic cells were seen in the tail vein injection group (a), but very few in the control group (b), the blank group (c) and the nanoparticles without laser irradiation group (d)
} 
A

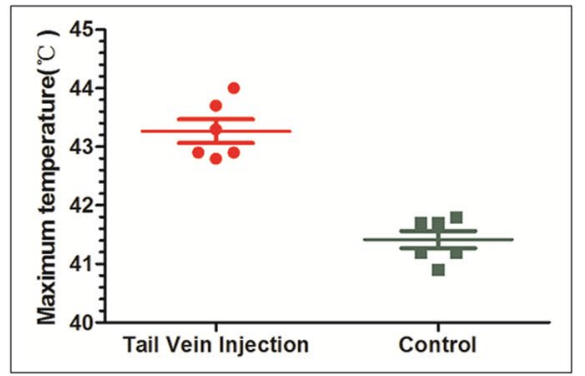

B

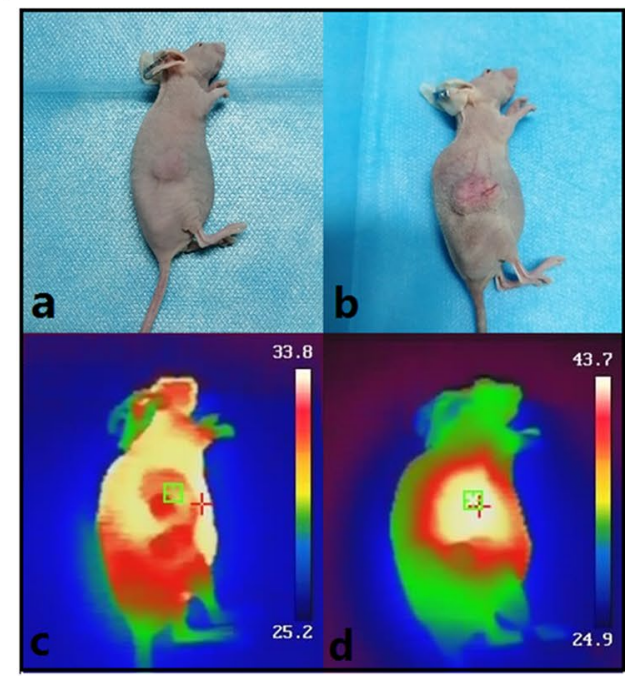

D

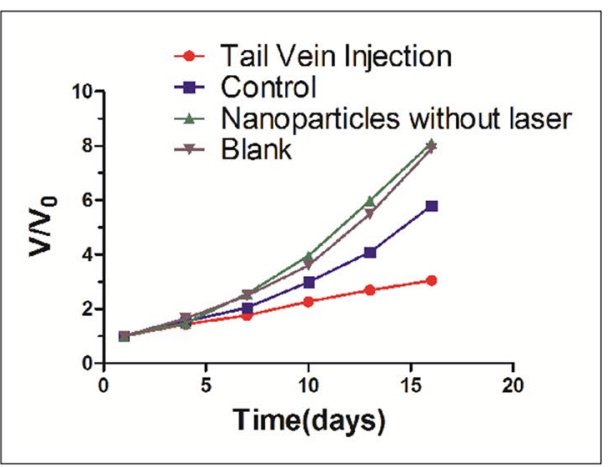

$\mathbf{F}$

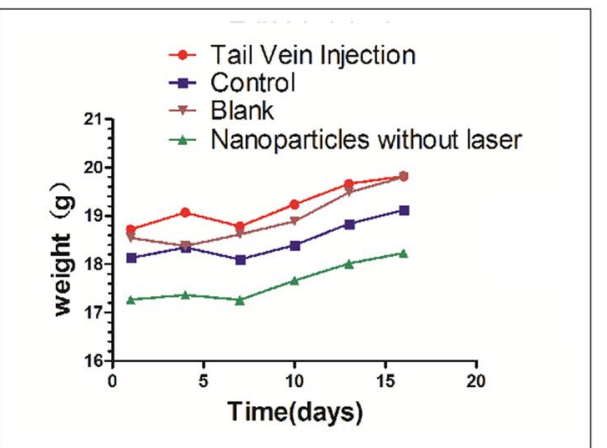

C

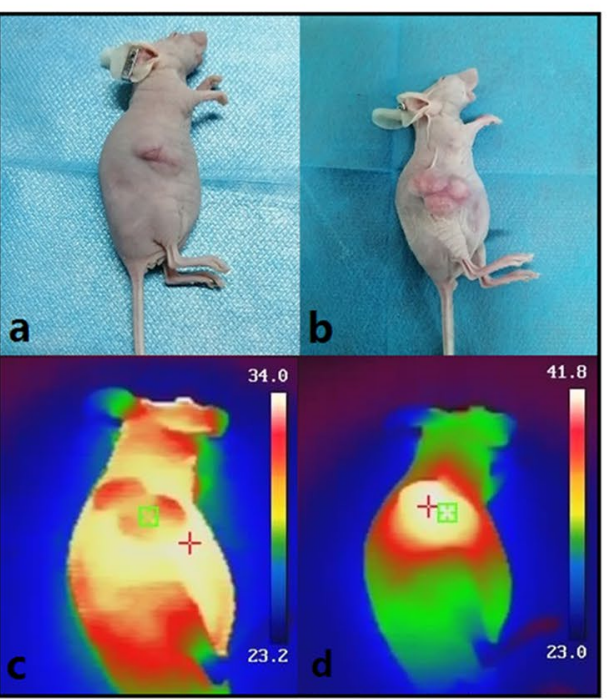

E

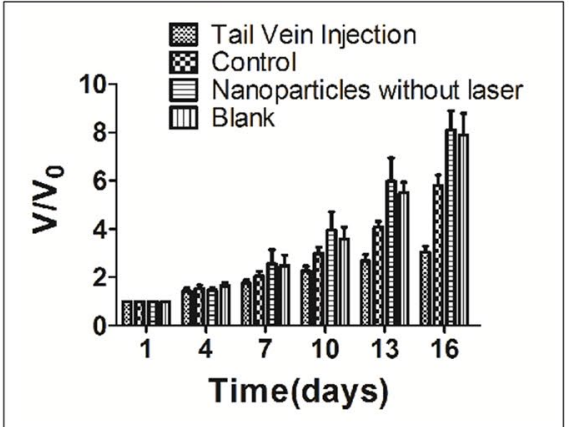

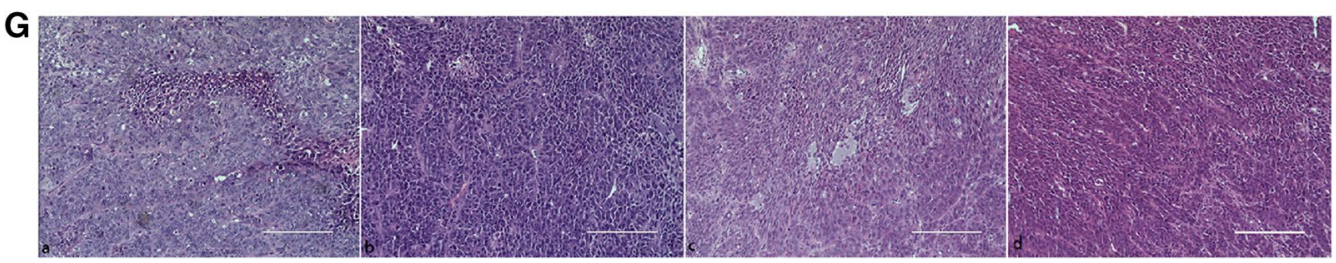

the key to successful treatment. In our study, one of the the limitations is that the concentration of USPIO-PEG$\mathrm{sLe}^{\mathrm{x}}$ nanoparticles in the tumor area is not high enough. If an additional external magnetic field is applied to the tumor area, it may be able to increase the concentration of USPIO-PEG-sLe ${ }^{\mathrm{x}}$ nanoparticles in the tumor to improve the PTT effect because USPIO-PEG-sLe ${ }^{\mathrm{x}}$ nanoparticles is a superparamagnetic iron oxide nanoparticle. 


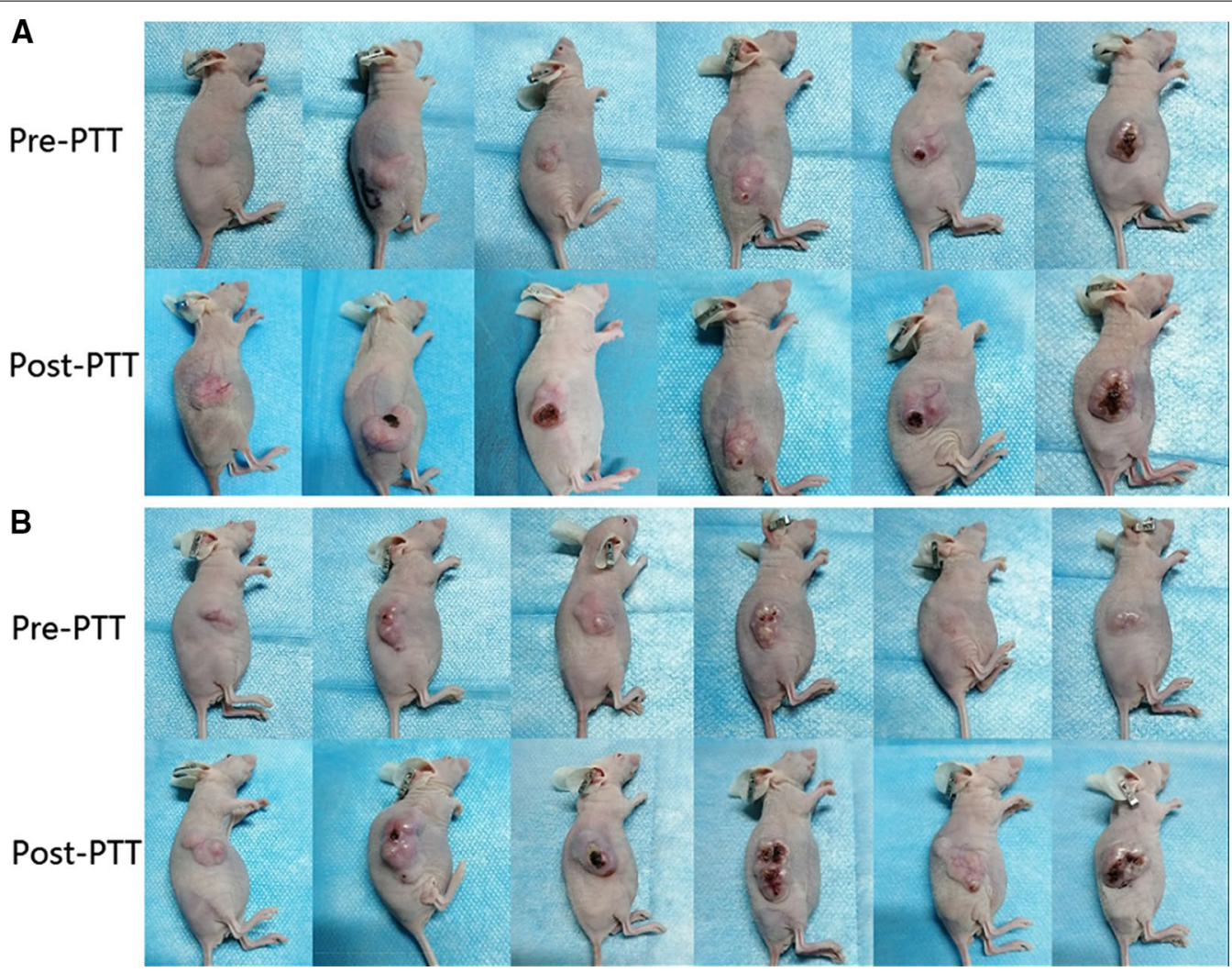

Fig. 8 A Tail vein injection group. B Control group. The top row were the tumor pre-treatment, and the bottom row were the tumor after five PTT

Due to the heterogeneity of tumors, the concentration of nanoparticles in the xenografts of nude mice in the same experimental group also varied, which is another limitation of this study. The third limitation is that sLe $e^{x}$ theoretically targets vascular endothelial cells, however, we did not experiment on vascular endothelial cells. And the fourth limitation is that we did not test the heat stability of USPIO-PEG-sLe ${ }^{\mathrm{x}}$ nanoparticles. In future, we will explore other protein molecules overexpressed of NPC cells. We do our best to improve the targeting property of the nanotheranostic platform in order to enhance the curative effect of PTT via couple specific ligands of sLe ${ }^{\mathrm{x}}$ and other protein molecules in USPIO-PEG simultaneously. Further improving the targeting property of this nanotheranostic platform, it may be become a new strategy for the treatment of NPC.

\section{Conclusions}

We synthesized the USPIO-PEG-sLe ${ }^{\mathrm{x}}$ nanotheranostic platform, and it may break through the bottleneck of traditional therapies of NPC and become a new strategy for NPC treatment.

\begin{abstract}
Abbreviations
NPC: Nasopharyngeal carcinoma; USPIO: Ultrasmall superparamagnetic iron oxide; PEG: Polyethylene glycol; sLe ${ }^{\mathrm{x}}$ : Sialyl Lewis X; USPIO-PEG-sLe': Polyethylene glycol-coated ultrasmall superparamagnetic iron oxide nanoparticlescoupled sialyl Lewis X; PTT: Photothermal therapy; MRI: Magnetic resonance imaging; IARC: The International Agency for Research on Cancer; PA:

Photothermal agent; NIR: Near-infrared; FDA: The American Food and Drug Administration; TEM: Transmission electron microscopy; DLS: Dynamic light scattering; FTIR: Fourier Transform Infrared; CCK8: Cell Counting Kit-8.
\end{abstract}

\section{Acknowledgements}

Not applicable.

\section{Authors' contributions}

GJ designed the study. QL, CM, LL, XZ, DC, YH, HH and WK performed experiments. QL, YZ and GJ wrote the manuscript. All authors read and approved the final manuscript.

\section{Funding}

This work was supported financially by the National Natural Science Foundation of China (81760533), the Natural Science Foundation of Guangxi Province (2018GXNSFAA281095) and Guangxi Clinical Research Center for Medical Imaging Construction (Guike AD20238096).

\section{Availability of data and materials}

All data generated or analysed during this study are included in this published article. 


\section{Declarations}

Ethics approval and consent to participate

This study was conducted in accordance with the guidelines of the Ministry of Science and Technology of China and relevant national regulations, and was approved by the Animal Protection and Welfare Committee of Guangxi Medical University.

\section{Consent for publication}

Not applicable.

\section{Competing interests}

The authors declare no potential conflicts of interest.

\section{Author details}

'Department of Radiology, Guangxi Medical University Cancer Hospital, Nanning 530021, China. ${ }^{2}$ Department of Chemistry and Biochemistry, Jackson State University, Jackson, MS 39217, USA.

Received: 9 March 2021 Accepted: 31 May 2021

Published online: 08 June 2021

\section{References}

1. Bray F, Ferlay J, Soerjomataram I, Siegel RL, Torre LA, Jemal A. Global cancer statistics 2018: GLOBOCAN estimates of incidence and mortality worldwide for 36 cancers in 185 countries. CA Cancer J Clin. 2018;68(6):394-424

2. Lee HM, Okuda KS, Gonzalez FE, Patel V. Current perspectives on nasopharyngeal carcinoma. Adv Exp Med Biol. 2019;1164:11-34.

3. Cao SM, Simons MJ, Qian CN. The prevalence and prevention of nasopharyngeal carcinoma in China. Chin J Cancer. 2011;30(2):114-9.

4. Chen Y-P, Chan ATC, Le Q-T, Blanchard P, Sun Y, Ma J. Nasopharyngeal carcinoma. Lancet. 2019:394(10192):64-80.

5. Andersson-Anvret M, Forsby N, Klein G, Henle W. Relationship between the Epstein-Barr virus and undifferentiated nasopharyngeal carcinoma: correlated nucleic acid hybridization and histopathological examination. Int J Cancer. 1977;20(4):486-94.

6. Yamamoto VN, Thylur DS, Bauschard M, Schmale I, Sinha UK. Overcoming radioresistance in head and neck squamous cell carcinoma. Oral Oncol. 2016;63:44-51

7. Zhang Y, Chen L, Hu GQ, Zhang N, Zhu XD, Yang KY, et al. Gemcitabine and cisplatin induction chemotherapy in nasopharyngeal carcinoma. N Engl J Med. 2019;381(12):1124-35.

8. Chow JC, Ngan RK, Cheung KM, Cho WC. Immunotherapeutic approaches in nasopharyngeal carcinoma. Expert Opin Biol Ther. 2019;19(11):1165-72.

9. Lee AW, Ma BB, Ng WT, Chan AT. Management of nasopharyngeal carcinoma: current practice and future perspective. J Clin Oncol. 2015;33(29):3356-64.

10. Mura S, Couvreur P. Nanotheranostics for personalized medicine. Adv Drug Deliv Rev. 2012;64(13):1394-416.

11. Abed Z, Beik J, Laurent S, Eslahi N, Khani T, Davani ES, et al. Iron oxidegold core-shell nano-theranostic for magnetically targeted photothermal therapy under magnetic resonance imaging guidance. J Cancer Res Clin Oncol. 2019;145(5):1213-9.

12. Zhang M, Wang W, Wu F, Yuan P, Chi C, Zhou N. Magnetic and fluorescent carbon nanotubes for dual modal imaging and photothermal and chemo-therapy of cancer cells in living mice. Carbon. 2017;123:70-83.

13. Zou L, Wang H, He B, Zeng L, Tan T, Cao H, et al. Current approaches of photothermal therapy in treating cancer metastasis with nanotherapeutics. Theranostics. 2016:6(6):762-72.

14. Shen S, Wang S, Zheng R, Zhu X, Jiang X, Fu D, et al. Magnetic nanoparticle clusters for photothermal therapy with near-infrared irradiation. Biomaterials. 2015:39:67-74.

15. Estelrich J, Busquets MA. Iron oxide nanoparticles in photothermal therapy. Molecules. 2018;23(7):1567.
16. Jaque D, Martinez Maestro L, del Rosal B, Haro-Gonzalez P, Benayas A, Plaza JL, et al. Nanoparticles for photothermal therapies. Nanoscale. 2014;6(16):9494-530.

17. Doughty ACV, Hoover AR, Layton E, Murray CK, Howard EW, Chen WR. Nanomaterial applications in photothermal therapy for cancer. Materials (Basel). 2019;12(5):779.

18. Mishra SK, Kumar BS, Khushu S, Tripathi RP, Gangenahalli G. Increased transverse relaxivity in ultrasmall superparamagnetic iron oxide nanoparticles used as MRI contrast agent for biomedical imaging. Contrast Media Mol Imaging. 2016;11(5):350-61.

19. Uchiyama MK, Toma SH, Rodrigues SF, Shimada AL, Loiola RA, Cervantes Rodriguez $\mathrm{HJ}$, et al. Ultrasmall cationic superparamagnetic iron oxide nanoparticles as nontoxic and efficient MRI contrast agent and magnetictargeting tool. Int J Nanomed. 2015;10:4731-46.

20. Zhou Z, Sun Y, Shen J, Wei J, Yu C, Kong B, et al. Iron/iron oxide core/shell nanoparticles for magnetic targeting MRI and near-infrared photothermal therapy. Biomaterials. 2014;35(26):7470-8.

21. Jubeli E, Moine L, Vergnaud-Gauduchon J, Barratt G. E-selectin as a target for drug delivery and molecular imaging. J Control Release. 2012;158(2):194-206.

22. Bevilacqua MP, Stengelin S, Gimbrone MA Jr, Seed B. Endothelial leukocyte adhesion molecule 1: an inducible receptor for neutrophils related to complement regulatory proteins and lectins. Science. 1989;243(4895):1160-5

23. Kang SA, Blache CA, Bajana S, Hasan N, Kamal M, Morita Y, et al. The effect of soluble E-selectin on tumor progression and metastasis. BMC Cancer. 2016;16:331.

24. Xia HZ, Du WD, Wu Q, Chen G, Zhou Y, Tang XF, et al. E-selectin rs5361 and FCGR2A rs1801274 variants were associated with increased risk of gastric cancer in a Chinese population. Mol Carcinog. 2012;51(8):597-607.

25. Jin GQ, Liu SY, Kang W, Huang M, Wang DP, Qu S, et al. Quantitative expression analysis of metastasis-related ELAM-1 in nasopharyngeal carcinoma. Int J Clin Exp Med. 2017;10(1):808-13.

26. Gout S, Tremblay PL, Huot J. Selectins and selectin ligands in extravasation of cancer cells and organ selectivity of metastasis. Clin Exp Metastasis. 2008;25(4):335-44

27. Yang S, Chen C, Qiu Y, Xu C, Yao J. Paying attention to tumor blood vessels: cancer phototherapy assisted with nano delivery strategies. Biomaterials. 2021;268:120562.

28. Zhou Z, Yan Y, Wang L, Zhang Q, Cheng Y. Melanin-like nanoparticles decorated with an autophagy-inducing peptide for efficient targeted photothermal therapy. Biomaterials. 2019;203:63-72.

29. Sharma G, Jagtap JM, Parchur AK, Gogineni VR, Ran S, Bergom C, et al. Heritable modifiers of the tumor microenvironment influence nanoparticle uptake, distribution and response to photothermal therapy. Theranostics. 2020;10(12):5368-83.

30. Sorrin AJ, Kemal Ruhi M, Ferlic NA, Karimnia V, Polacheck WJ, Celli JP, et al. Photodynamic therapy and the biophysics of the tumor microenvironment. Photochem Photobiol. 2020;96(2):232-59.

\section{Publisher's Note}

Springer Nature remains neutral with regard to jurisdictional claims in published maps and institutional affiliations.

Ready to submit your research? Choose BMC and benefit from:

- fast, convenient online submission

- thorough peer review by experienced researchers in your field

- rapid publication on acceptance

- support for research data, including large and complex data types

- gold Open Access which fosters wider collaboration and increased citations

- maximum visibility for your research: over 100M website views per year

At BMC, research is always in progress.

Learn more biomedcentral.com/submissions 